\title{
The Equivalence and Non-Equivalence of Proverbs Across Cultures (Indonesian and English)
}

\author{
Syahron Lubis \\ University of Sumatera Utara, Indonesia \\ Email: ronlubis@gmail.com
}

\begin{abstract}
The aim of the present study is to examine whether or not proverbs, culturally-related medium of communication, are equivalent across cultures. The proverbs compared are derived from Indonesian and English cultures, as two distinct cultures. Fifteen Indonesian proverbs and fifteen English proverbs have been compared to prove whether or not they are equivalent in terms of meaning, linguistic form and culture. The proverbs are collected from a list of well-known Indonesian and English proverbs. Since almost the thirty proverbs are expressed in metaphorical meaning and since Indonesian is still foreign to many international readers the literal meaning of lexical items found in the proverbs have been glossed in brackets followed by the explanation of the metaphorical meaning of the thirty proverbs. Ten Indonesian proverbs are found to be equivalent in terms of meaning to ten English proverbs. In terms of linguistic structure they are almost equivalent that is they are expressed mostly in sentence structure. But they are different in the use of lexical items that constitute the proverbs. Five Indonesian proverbs are found to be nonequivalent to five of English in terms of meaning and the lexical items used to build the metaphor. Thus it is found out that fifteen Indonesian proverbs are equivalent to fifteen English proverbs and five Indonesian proverbs are found to be nonequivalent to five English proverbs.

Keywords---culture, equivalent, meaning, metaphor, proverb.
\end{abstract}

\section{Introduction}

Human beings use language as a tool of communication. Members of the society interact using the language mostly verbal language. With the verbal language a speaker can convey his intentions to his listener. He can express his ideas, feelings, what he likes and dislikes etc to his listener.

As a tool of communication, language provides choices for the user. The user or the speaker can express his thoughts directly using literal/denotative meaning or indirectly use non-literal/connotative meaning. The effect of using denotative meaning and connotative meaning can be different for the listener. For example, praising a classmate by using a metaphor as Julia is a star in our class will have a different effect on the listeners from using literal meaning as Julia is the best student in or class.

Thus besides being expressed literally, meaning can be also expressed idiomatically, metaphorically or by using fixed expressions like English Ladies and gentlemen, Yours sincerely or proverb like To carry coals to New Castle. Such linguistic forms are commonly used as a medium of expressing meaning (Baker, 1992).

This study will look at how meaning is expressed in a proverb of one language (Indonesian) and to find out whether or not a similar meaning is also expressed in a proverb of another language (English) or in other words is a proverb in one language equivalent or not equivalent to a proverb in another language?

English and Indonesian are two different languages. Both are members of two different language families, i.e. English is a member of Indoeuropean Language Family while Indonesian is a member of Austronesian Language Family. In terms of culture both Britain and Indonesia are also different. British society adopts individualism and equality ideology while Indonesian society adopts collectivism and hierarchy/vertical ideology. Since language is part of culture it is believed that the ideas expressed by means of proverbs might be different. The difference might be due to the different cultural experiences of the speakers of the two different languages.

ISSN 2632-9409

Received Jan 10, 2018 / Accepted Jun 20, 2018 / Published Jul 05, 2018 


\section{Literature Review}

What is a proverb? According to Adler as cited in Katan (1999) a proverb contains beliefs which are very deepseated and ...they are believed to be true. And The Macquarie Dictionary (1985) defines a proverb as:"A short popular saying, long current, embodying some familiar truth or useful thought in expressive language." While in Kamus Besar Bahasa Indonesia (1988) a proverb is defined as:"Ungkapan atau kalimat-kalimat ringkas padat, yang berisi perbandingan, perumpamaan, nasihat-nasihat, prinsip hidup atau aturan tingkah laku." This quotation means that proverbs are expressions or short sentences containing comparisons, similes, advice, principles of life or rules of behavior. Thus a proverb may express truth in life, advice, what we should and should not do, principles of life also comparison of one thing with another.

Proverb is widely known in any society and is relatively much used although a proverb is normally inserted into a conversation or a discourse if the meaning of the proverb is relevant or will support the truth of the speaker's idea in the conversation or the discourse. For example, seeing a son behaves like his father English speakers would say "An apple falls not far from its tree" or Indonesian speakers would say "Cucuran atap jatuhnya ke pelimbahan juga" (drop of water from the roof will surely falls into the ditch) which has similar meaning to the English proverb.

There are some functions of proverb as to express truth as in Lost time is never found again, to warn people as in Pride comes before a fall, to advise people to do positive thing as in Strike while the iron is hot, to advise people not to blame people or things for what they do not do as in A bad workman blames his tools.

An idiom or fixed expression (a proverb is a type of idiom) may have no equivalent in other languages since the speakers of one language may have different cultural experiences from the speakers of other languages. On the other hand a proverb in one language may have its equivalent in another language as exemplified by Baker (1992) as To sing a different tune (to say or do something that signals a change of opinion) is equivalent to Chinese Chang-duk tai-xi.A Mandailingnese proverb, an ethnic language of Sumatra (Lubis, 2012) Gumonando na gonting sian na tos (Better frayed (string) than broken off) is similar in meaning to English Half a loaf is better than none. Samovar et al., (2007) state that because all people may have the same experiences so a proverb in one culture may be equivalent to another in other cultures. They prove the idea with these two proverbs: "One who does not honor the penny is not worthy of the dollar (Germany)" and "A penny saved is a penny earned (USA). These proverbs mean being economical is a good habit. In Indonesia a proverb with similar meaning is "Hemat pangkal kaya (Being thrifty is the source of wealth)".

When we look at the literal meanings used, it seems that some proverbs in one language may have been borrowed from a foreign language via translation. The frequently used Indonesian proverb Tong kosong nyaring bunyinya (empty vessel has loud sound) in terms of structure, the words used and their meaning indicate that it is the translation of the English Empty vessels make the most noise.

A society may differ in viewing people, animal or plant which is used in a proverb from the other societies. For example, for Mandailingnese society a mouse deer is viewed as a wise and clever animal. A mouse deer is a symbol of intelligence. Thus in a traditional ceremony a metaphorical expression like "Mangido bisukma hita tu landuk" (Let's request wisdom from a mouse deer) is often heard. On the other hand for Malay society a mouse deer is viewed as a cunning animal. It can be seen in many Malay folk stories. Stupidity is symbolized by a sheep in U.S.A., by a donkey in Saudi Arabia (Baker, 1992) and by a cassowary in Papua New Guinea (Larson,1984).

\section{Research Method}

Thirty proverbs, 15 of Indonesian and 15 of English have been compared in order to find whether or not the 15 of Indonesian proverbs and the 15 of English are equivalent in meaning, syntactic structure and culture (the referents used to constitute the proverbs).

Fifteen Indonesian proverbs were collected from Kumpulan Peribahasa Lengkap Dengan Artinya (maribelajarbk.web.id) and the 15 English proverbs were collected from the List of Proverbs (tww.id.au).

Before comparing and analyzing the meaning of the proverbs, in order to help the reader understand the lexical meaning of the Indonesian proverbs, the lexical items of Indonesian used in the proverbs were glossed within a bracket. Then comparison of meaning was made to find out whether or not the two proverbs (Indonesian and English) are equivalent in meaning. The lexical items used to constitute the proverbs were also examined in order to know the types of words used to build the proverbs. This was done because language is part of culture and lots of words have been coined to symbolize the things which exist around the speakers of a certain language and which do not exist around the speakers of another language. The syntactic structure of the two proverbs were also compared and examined. 


\section{Findings and Discussion}

Twenty proverbs i.e. ten Indonesian proverbs and ten English proverbs have been found. Their meaning is concerned with different matters.

Indonesian and English Proverbs which are Equivalent

The following ten of Indonesian and ten of English proverbs have been found to be equivalent.

Proverb 1 (Indonesian) Nasi sudah menjadi bubur (Rice has changed to porridge).

Proverb 1 (English) It is no use crying over spilt milk.

This Indonesian proverb is equivalent to English It is no use crying over spilt milk. The two proverbs mean that 'what has happened or has been done cannot be returned to its previous condition'. So it is no use regretting what had happened or had been done.

There are no linguistic contrasts between the two proverbs. Both are made in a simple, positive, and declarative sentence. But in terms of culture, in the English proverb, it is milk, as a valuable thing that has become useless while in Indonesian proverb it is rice. We know that rice is a common commodity and is used as a daily foodstuff for most Indonesians while for Englishmen rice is not so common while milk is a daily drink for most of the people.

Proverb 2 (Indonesian) Masuk kandang kambing mengembik, masuk kandang lembu menguah (Entering a stable of goat bleat, entering a cowshed moo).

Proverb 2 (English) When in Rome do as Romans do.

The Indonesian proverb is equivalent to English When in Rome do as Romans do. The two proverbs mean that one should adapt himself to a new situation where he is. He should follow the traditions of the people of the new situation. Both proverbs are expressed in a simple sentence, however, the English proverb uses the imperative sentence "Do as Romans do" whereas the Indonesian proverb is only a kind of advice "When entering a stable of goat bleat, please".

There is a great cultural contrast between the two proverbs. The English proverb uses the city of Rome and its citizens to be obeyed while the Indonesian proverb uses goats and cows which are gathering in a stable to be followed or imitated. Both the Englishmen and Indonesians are quite familiar with goats and cows but they do not use the same thing "to be followed or obeyed". The English speakers use Rome, a city which is close to Britain but it is quite far from Indonesia.

Proverb 3 (Indonesian) Awak yang tak pandai menari, dikatakan lantai terjungkit (One who cannot dance blames that the floor is not flat).

Proverb 3 (English) A bad workman blames his tools.

The Indonesian proverb is equivalent to English A bad workman blames his tools. The two proverbs warn us that "It is not good to blame others because of our failure or for what we have done wrong". The two languages are different in using the words to build the metaphors. The Indonesian proverb uses dancer and floor while the English proverb uses workman and tools. So in terms of culture, there is no a significant difference between the two proverbs since both Englishmen and Indonesians are familiar with dancer and workman. The English proverb is expressed in a simple sentence while the Indonesian proverb is expressed in a complex sentence.

Proverb 4 (Indonesian) Tak ada rotan akarpun jadi (If there is no a rattan, a creeping root will do).

Proverb 4 (English) Better late than never.

The Indonesian proverb is equivalent to English Better late than never or to another one Half a loaf is better than none. The Indonesian and the English proverbs illustrate a situation that in life a little is still better than nothing at all. For example, if you cannot find a job offering a good career or good salary at the moment, a job with a small salary is much better than having no job at all.

The three proverbs have the same linguistic structure, that is, they are expressed in the simple statement. In terms of culture, the Indonesian proverb uses a rattan and a creeping root to build the metaphor. Rattan in Indonesian culture is a very useful thing. It grows well in the Indonesian forests. In the metaphor, rattan is used as a good and strong string to tie things. If there is no rattan a creeping root can be used instead though it is not as strong as a rattan. 
The English proverb Better late than never illustrates a meeting or a gathering situation where an attendant is still better coming late than being totally absent.

Proverb 5 (Indonesian) Habis gelap terbitlah terang. (After dark then bright).

Proverb 5 (English) After storms comes the calm.

The Indonesian proverb is equivalent to the English After storm comes the calm. The two proverbs mean that in life nothing is eternal. Everything will come to its end. One who fails today may win tomorrow. One may not be poor all the time but his life may change in future. Both proverbs are expressed in the simple and positive statement. Both proverbs use the nature's phenomenon to build the metaphor. The Indonesian proverb uses the change of night to daytime while the English one uses the change of stormy situation to a normal situation.

Proverb 6 (Indonesian) Air beriak tanda tak dalam (Rippling water (river) is a sign of a shallow water).

Proverb 6 (English) Empty vessels make the most noise.

The Indonesian proverb is equivalent to English Empty vessels make the most noise. The two proverbs mean that a person who talks a lot usually knows less. In addition to Air beriak tanda tak dalam, Tong kosong nyaring bunyinya is also known in Indonesian which is exactly similar both in structure and meaning to Empty vessels make the most noise but since it is the literal translation of the English proverb, it is quite probable that it is not an original Indonesian proverb but only a literal translation of the English one.

In terms of linguistic structure, the two proverbs belong to a simple statement. The Indonesian proverb uses $a$ rippling water/river while the English proverb uses empty vessels to build the metaphor.

Proverb 7 (Indonesian) Bagai mencincang air (Like chopping the water).

Proverb 7 (English) Like looking for a needle in a haystack

This proverb is equivalent to English Like looking for a needle in a haystack or As a wild goose chase. Both the Indonesian and the English proverbs refer to an effort which will never be accomplished or successful or it is a useless effort.

In terms of syntactic structure the two proverbs belong to phrase and in terms of culture, they are different. The Indonesian proverb uses an act of chopping or cutting water, an act which is impossible to succeed while the English one uses an act of looking for a very small thing (needle) in a large pile of hay which is also an impossible and useless effort. In Indonesian a literal translation of the English proverb is also known, that is Bagai mencari jarum dalam jerami and Bagai menegakkan benang basah (Like erecting a wet thread) is also frequently used.

Proverb 8 (Indonesian) Biduk satu nahoda dua (One ship two captains).

Proverb 8 (English) Too many cooks spoil the broth.

The Indonesian proverb is equivalent to English Too many cooks spoil the broth. The two proverbs may mean that a team or an organization presided by more than one leader commonly will be ruined because the members of the team do not know whose leader's instructions to be followed or whose orders to be undertaken. The two proverbs are different in syntactic structure. The Indonesian one is actually a compound sentence: "There is one ship and there are two captains" which has been shortened to "One ship two captains". The English proverb is a simple sentence only. In terms of culture, the two proverbs are different. The Indonesian one uses biduk 'ship' and nahoda 'captain' to build the metaphor while the English one uses cooks and broth.

Proverb 9 (Indonesian) Sekali merangkuh dayung dua, tiga pulau terlampaui (Rowing once, two or three islands are passed by).

Proverb 9 (English) To kill two birds with one stone.

The Indonesian proverb is equivalent to English To kill two birds with one stone. The two proverbs show a beneficial effort. An effort can gain multiple results. For example, one who plants fruit trees around his home, besides he will get fruit from the trees he also does greening of his environment which is also useful to make the environment fresh and comfortable. In terms of syntactic structure the two proverbs are similar, i.e they are expressed in a simple sentence but the Indonesian proverb is expressed in a passive sentence while the English one is 
an inactive sentence. The Indonesian proverb uses a rowboat and islands to build the metaphor while the English one uses birds and stone. In Indonesian there are two more proverbs having the same meaning as that, they are Sambil menyelam minum air (While diving. drinking water) and Sambil berdiang nasi masak (While warming up the body near the fire (usually near a fireplace in a cold morning) the rice is cooked). The third one is a very old proverb and it is not as popular as the first and the second. Indonesian youths when asked whether they know the proverb they generally say 'no'.

Proverb 10 (Indonesian) Kalau tidak angin bertiup, takkan pohon bergoyang (If there is no wind blowing, a tree will not shake).

Proverb 10 (English) Where there is no smoke there is no fire.

The Indonesian proverb is equivalent to the English Where there is no smoke there is no fire. The two proverbs indicate a relation of cause and effect. A tree is usually shaken by the wind. If the wind does not blow the tree it will not shake and without fire, there will be no smoke. The same is true in human life. For example, people will not go or move to a new place if there is no possibility of having a better life or better situation. Or one has not done a particular thing if there is no something which drives him to do it. In Indonesian, there is another similar and which sounds more interesting proverb. Kalau tak ada berada masakan tempua bersarang rendah (If there is no cause it is impossible that a weaverbird makes its nest at a low place. This proverb literally means that a weaverbird makes its nest close to the ground because there is a colony of bees nearby which can sting anyone who comes close or pass by near the tree. If there are no bees weaverbirds normally make their nests at high branches of the tree.

The two proverbs are expressed in a form of a complex sentence. In terms of culture, the Indonesian proverb uses the relation between tree and wind to build the metaphor while the English one uses the relation between fire and smoke.

English Proverbs which do not have Equivalents in Indonesian

Five English proverbs have been found to have no equivalents in Indonesian. They are shown as follows.

Proverb 1 Time is money

The very well- known and frequently used proverb indicates that time is equivalent to money. It means that time is as valuable as money. Time can be both possessed and lost and it can be also bought and sold as money. Time can be exchanged for anything and the amount of time is limited. When time is lost it is never found again. There is no such a proverb in Indonesian which regards time as a very precious and limited commodity.

\section{Proverb 2. Time and tide wait for no man.}

The proverb indicates that time runs naturally. No one can stop the time. The run of time neither can be slowed down nor can be sped up. When a moment is not used, it is lost forever. A chance never comes twice. In Indonesian, a similar proverb is not found. However, in a religious context of Muslim, it is also said that death comes on time. It cannot be slowed down nor can it be accelerated even a minute.

\section{Proverb 3. First comes first served.}

The English proverb which is also related to the importance of time means that how important it is to use the time. Be the first one! Don't be the later ones because it is the first which will be served first not those who come later. Since the time is so limited there will be a possibility that the time is not enough for those who come late. Actually, in Indonesian society, one who comes early to an event is appreciated but for many people, it is still a habit to come to an event a bit later than the scheduled time.

\section{Proverb 4. The early bird catches the worm.}

This proverb is also related to the use of time. One who is able to use the time/opportunity earlier than the others he will get the benefit of being served first or he will have the first chance to use or to enjoy something. He may also get a dispensation if he is the first person who can fulfill, for example, an organizing committee's requirement. 
Proverb 5. Life begins at forty.

This proverb is again related to time. The proverb indicates that human maturity physical and mental is usually reached when one has reached the age of forty. That is the time when one is fully aware of what life is. In Indonesian culture, one's maturity is not normally measured from his age but one is regarded as mature when he/she is married. Thus a saying like Selamat menempuh hidup baru (Have a happy new life) is often spoken to a newly married couple.

Indonesian Proverbs which do not have Equivalents in English

It is found that there are also five Indonesian proverbs which do not have equivalent in English as shown below.

Proverb 1. Biar lambat asal selamat tidak lari gunung dikejar. (As long as it is safe, being late does not matter. The mountain will not escape).

The well-known proverb in Indonesian society means that safety is a priority. Being safe is better than to economize time. So, time is viewed as an abundant commodity or it is unlimited. "Tidak lari gunung dikejar" (The mountain will not escape) indicates that a stationary object like mountain will never move so it is useless to chase it. It seems that the people believe that a stationary object is absolutely immovable. But actually a stationary natural object like an island which is believed to remain there forever, because of a natural disaster, it may disappear or lost.

\section{Proverb 2. Banyak anak banyak rezeki (Many children much fortune).}

Many people believe that anyone has his own fortune. So the more children you have the more fortune you will get and conversely the fewer children you have the less fortunate you will have. In Indonesia, before people believed that wealth or riches were limited, they did not limit the number of their children. It was quite common in the past that there were seven to eight children in a family. Nowadays people know and realize, by means of a mathematical calculation, that the growth of wealth is no as fast as the population growth so they begin to limit the birth of their babies by joining the Family Planning Program.

\section{Proverb 3. Surga di bawah telapak kaki ibu (Heaven is under the mother's sole).}

The proverb which is based on Muslim faith means that mother is one who must be honored and loved by her child. A child has no right to oppose or disobey his mother. The status of a mother is so high that it is incomparable to that of a child. So, metaphorically the highest position of a child is located at the lowest part of the mother's body (sole of the foot).

\section{Proverb 4. Ayam bertelur di lumbung padi mati kelaparan (A chicken laying eggs in a rice barn dies of hunger).}

The Indonesian proverb indicates a paradoxical situation. A chicken may die at a place where food is abundant. The chicken should be fine because a lot of food is available but on the contrary, the chicken dies. A similar situation can be found in human life. There may be people or society who suffer from economic problems where abundant natural resources are available at the place they live. In some societies because of the inability of the people to manage the natural resources of their region they remain underdeveloped and poor.

Proverb 5. Bekerjalah seolah-olah engkau akan hidup selamanya dan beramallah seolah-olah engkau akan mati besok (Work as if you will live forever and pray (perform good deed as requested by God) as if you will die tomorrow.

This proverb motivates us to perform two tasks. First, we are required to work to find necessary things needed to maintain our lives in this world and to perform good deed as ordered by God to collect merits or rewards for our safety in the hereafter. This is a slogan in Muslim context in order to reach a balance in life. Since Muslims believe that there is a hereafter, life on the earth and in the hereafter should be balanced. One should not only want to be successful on earth but forget to make preparation for his life in the hereafter (by obeying God's rules and by performing good deeds). On the other hand, one should not only think of his happy life in the hereafter but does not care of his life on the earth. 
Ten proverbs of Indonesian and ten of English have been found to have been equivalent in meaning They also have the same function.

Proverb 1 of Indonesian and 1 of English function to remind people that it is useless to regret for what has happened or done wrongly. The English proverb uses spilt milk and the Indonesian proverb uses the change of rice to porridge to symbolize that what has gone never comes back again. People should realize that if something wrong has been done it will become a past happening. It would be better to avoid making the same mistake in the future rather than to imagine as if the mistake has had never occurred.

Proverb 2 of Indonesian and $\mathbf{2}$ of English are also equivalent in meaning. The two proverbs also have the same function that is to advise people to adapt themselves to a new situation they face. The Indonesian proverb uses the situation of entering a stable of goat and the English proverb uses the situation of going to Rome to symbolize that people should adapt themselves to a new situation or place they visit. Since people live in different cultures people cannot bring their own customs and traditions to the new place because it is quite possible that their customs are not suitable to the new culture but even it is rejected. For example, to hand somebody a thing with the left hand is taboo in Indonesian culture but not in British culture.

Proverb 3 of Indonesian and $\mathbf{3}$ of English is similar in meaning or they are equivalent. The two proverbs have the same function that is to remind people of not blaming others for the fault they have done themselves. It is not a good attitude not to admit our own weakness or fault.

Some people feel it hard to admit that they have committed a fault even though they cannot hide it.

Proverb 4 of Indonesian and no 4 of English are equivalent in meaning. They also have the same function that is to remind people that to possess is better than not to possess even though the thing owned is only a little or a small amount. The Indonesian proverb uses a creeping root to replace a rattan and the English proverb uses half a loaf to build the metaphors. In a critical situation where what we badly need does not exist, a small part of the thing we need or the second class of the thing we need will be very helpful.

Proverb 5 of Indonesian and no 5 of English are also equivalent in meaning. They function to remind people that nothing is eternal. Everything can change. The Indonesian proverb uses the change of darkness to brightness and the English one uses the change of storm to calm to build the metaphorical meaning. We often observe the change in people's life. In the past one was only a commoner but a few years later we see that he has changed to a VIP. Sometimes life is likened to rotation of a wheel of a bull-drawn cart. There is a time where part of the wheel rotates to the lowest position but at another time it rotates to the highest position.

Proverb 6 of Indonesian and 6 of English are equivalent in meaning. They function to show a state that a person who always boasts of himself or his family is usually contrary to reality. The Indonesian proverb uses rippling water and the English one uses the empty vessel to symbolize the boastful person. It is not certain that a person who talks a lot knows a lot. On the other hand, a person who talks a little knows only a little. In Indonesian culture, it is common that a person who knows a lot usually talks a little and is not boastful in the sense that he does not talk as if he knows everything. He is fully aware that it is impossible for a person to know everything. Such a person is likened to grains of rice which bow more when they become heavier (They have more content).

Proverb 7 of Indonesian and no 7 of English are equivalent in meaning. The two proverbs function to remind people not to do things without benefits. An effort may be useless and no possibility of being successful. The English proverb uses looking for a needle in a haystack and the Indonesian proverb uses chopping water. Both are useless efforts. In a broader sense, it would be better to do a small thing which will give us real benefits than to imagine doing a huge thing with enormous benefit but which is never realized. Gambling is a kind of effort whose success cannot be predicted.

Proverb 8 of Indonesian and $\mathbf{8}$ of English are equivalent. The two proverbs remind people that it is not good to appoint more than one person to be a leader of one group or team. If there are two leaders, the members of the team do not know which leader to be obeyed or whose order to be carried out. The Indonesian proverb uses one ship with two captains and the English proverb uses many cooks and broth to build up the metaphors. Even in a family, the children will get confused if the father and the mother give different guidance or show different examples to their children.

Proverb 9 of Indonesian and 9 of English are also equivalent in terms of meaning. The two proverbs show people that an action may produce multiple advantages. The Indonesian proverb uses one row of a rowboat and the English proverb uses bird and stone to build up the metaphors. People sometimes may find a situation or an event which brings multiple benefits. For example, going abroad to study besides gaining knowledge one may also experience the cultures and learn the language used in the region.

Proverb 10 of Indonesian and $\mathbf{1 0}$ of English are equivalent in meaning. They function to show us a truth that there must be a cause of one happening. For example, there must be a cause of one's success and there must be a cause of one's failure. The Indonesian proverb uses wind and tree as a cause and result while the English proverb 
uses fire and smoke to build the metaphors. In Indonesian culture, we may also hear people say "Kalau tidak ada api mana mungkin ada asap" which is equivalent in terms of both structure and lexical meaning to "Where there is no smoke there is no fire". The proverb shows a logical relation of two things where one is a cause and another is an effect. Of course, there will be no effect without something that may cause the effect. How can one be knowledgeable about something without learning seriously or how can one become rich without hard work?

Five of English proverbs and five of Indonesian have been found to be different. It is interesting to compare the five English proverbs and the five of Indonesian proverbs which are not equivalent. The five proverbs of English, in general, are related to the use of time. The proverbs indicate that how important and valuable the time is since the availability of time is so limited. One who can make use of the time will gain advantages and on the other hand, one who cannot make use of the time will undergo loss. So far a proverb which indicates the high value of time in Indonesian society has not been found. The proverb which is related to the usefulness of time does not indicate the importance of time but safety is far more valuable than saving the time (being safe is better than being late). In Javanese society of Indonesia, we find a similar proverb "Alon-alon asal kelakon" which means "The priority of safety over saving time'.

The other four Indonesian proverbs are not related to time. The proverb "Banyak anak banyak rezeki" indicates the belief that one can collect a certain amount of wealth. So more people will collect more amount of wealth. A long time ago when the number of people was rare and the land was large enough one may possess a piece of land to cultivate but now since the population growth is faster than the growth of the availability of land a piece of land must be shared for more than one people.

The proverb "Surga di bawah telapak kaki ibu" indicates the incomparable status between a child and his mother. A child is so unequal to his mother who bore him. Indonesian society which beliefs in collectivistic and hierarchical culture a senior is highly respected by a junior. Parents, grandparents elder brothers/sisters are among those whom the younger people should respect.

The proverb "Ayam bertelur di lumbung padi mati kelaparan" indicates an absurd situation. It is an unusual situation. People who live in a region where everything is available should be prosperous. But what happens is contrary to expectation. Some countries are known to be rich in natural resources but since the people cannot exploit the natural resources, the rich supply of the natural resources remain useless for them.

The desire for balanced life in this world and life in the hereafter is indicated by the proverb "Bekerjalah seolaholah engkau akan hidup selamanya dan beramallah seolah-olah engkau akan mati besok". For religious people (Muslims) believe that besides life in this world there will be living in the hereafter. They believe also that life in the world is only temporary while life in the hereafter is eternal. However, even though life in the world is only short it does not mean that we can ignore it. We should strive for a better life. Both the worldly life and the life in the hereafter should be balanced. We should not live only to earn a good living but we should also prepare ourselves to fulfill the requirements of good life in the hereafter by obeying the God's orders and by leaving behind what is forbidden.

\section{Conclusion}

The present study has found out that even though proverbs are culture-bound linguistic forms, there are proverbs of one culture which are equivalent to proverbs in another culture. The ideas expressed in the two cultures are similar but the way the ideas are expressed, of course, is not similar. The lexical items used to construct the metaphorical meaning are different. This finding is justified by the equivalence often Indonesian proverbs to ten English proverbs. The equivalence of one proverb in one culture to one proverb in another culture probably is due to the same cultural experiences.

However, there are proverbs in one culture which have no equivalents in another culture. In this study, five English proverbs are not equivalent to Indonesian proverbs and similarly, five Indonesian proverbs are not equivalent to the five English proverbs. The five English proverbs are really concerned with time The Indonesian proverb number one is concerned with the priority of safety over the supply of time, the second one is concerned with the belief that children are the sources of fortune, the third one is concerned with the high position of a mother and the low position of the child. The fourth is concerned with a paradox where one dies of hunger in a situation where food is abundant and the fifth is concerned with the belief that life on earth should be in balance with the life in the hereafter.

\section{Acknowledgements}

The author would like to thank the editor for their valuable time and advice. 


\section{References}

Ali, Z., \& Bahasa, P. (1983). Sistem morfologi kata kerja bahasa Aceh. Pusat Pembinaan dan Pengembangan Bahasa, Departemen Pendidikan dan Kebudayaan.

Baker, M. (2018). In other words: A coursebook on translation. Routledge.

Delbridge, A., \& Yallop, C. (1996). The macquarie dictionary. English Today, 12(1), 11-14.

Katan, D. (2014). Translating cultures: An introduction for translators, interpreters and mediators. Routledge.

Larson, M. L. (1984). Meaning-based translation: A guide to cross-language equivalence. Lanham: University press of America.

Lubis, S. (2018). The Equivalence and Nonequivalence of Proverbs Across Cultures (Indonesian and English). International Journal of English Linguistics, 8(4), 253.

Miller-Naudé, C. L., \& Naudé, J. A. (2010). The translator as an agent of change and transformation: The case of translating biblical Proverbs. Old Testament Essays, 23(2), 306-321.

Samovar, L. A., McDaniel, E. R., Porter, R. E., \& Roy, C. S. (2015). Communication between cultures. Nelson Education.

Suryasa, I. W. (2016). Potential and actual expression in blocking system (morphology studies). International Journal of Research in Social Sciences, 6(3), 682-691. 